6

\title{
Flood, Fruit, ANd SATAN
}

In 1961, young-earth creationism exploded onto the American scene with the publication of The Genesis Flood by John Whitcomb Jr. and Henry M. Morris. By any standard the book was a blockbuster-more than two hundred thousand copies sold through twenty-nine printings by the mid1980s. ${ }^{1}$ Over the course of the 1960s, Morris took the lead in reviving an organized antievolution movement. By 1970, he succeeded in creating the infrastructure for the Institute for Creation Research (ICR). It served as the standard-bearer in the public battle against evolutionary science for the next thirty years. The success of Morris's efforts was an ironic testament to how much ground evolutionary science had gained, and not only in the universities and modernist churches. The Soviet Union's successful launching of Sputnik in 1957 sparked a massive effort by the US government, through the National Science Foundation (NSF), to retool high school biology education. One result was the NSF-funded University of Colorado-based Biological Sciences Curriculum Study. By 1963 the initiative had produced a series of attractive biology textbooks, infused with 
the modern evolutionary synthesis, that were adopted in more than half the nation's public schools. ${ }^{2}$

As Morris and his counterparts struck back, they were careful to declare that their interest in spreading creationist ideas was educational and not political. They recruited creationist scholars, most with PhDs, to staff the Creation Research Society and write articles for its journal that reflected their scientific training. And yet, the process that led to the ICR at the end of the tumultuous decade of the 1960s was thoroughly imbued with political concerns. The text of Morris's early works-including Genesis Flood-includes explicit references to communism as a fruit of evolution. The political context in which Morris built his organizational base was critical to its success. A rich network of anticommunist activists nourished Morris's Red Dynamite ideas. Among them were Fred Schwarz, David Noebel, James Bales, John N. Moore, R. J. Rushdoony, and Tim LaHaye. The establishment of the ICR reminds us that the "radical" 1960s generated social movements on both sides of the political spectrum. While young-earth creationists were just getting started on an organizational level, they would soon help to redefine the political contours of the American religious landscape.

Whitcomb and Morris, the duo who produced The Genesis Flood, were in some ways unlikely candidates for the role. The son of a US Army colonel, John Whitcomb Jr. was born in 1924 in Washington, DC, into a nominally Christian Episcopalian family. As a boy, he lived in China, where his father's regiment was stationed to protect American interests in the chaos of the Chinese Civil War. Back in the US he attended the McCallie School, an exclusive Christian prep academy in Chattanooga. After being ruled ineligible for West Point because of poor eyesight, Whitcomb attended Princeton starting in the fall of 1942 and loved his science courses, especially one in evolutionary geology. As he later recalled, "I was a total evolutionist." ${ }^{3}$

Whitcomb's road to creationism began during his freshman year, when Donald Fullerton, the leader of the Princeton Evangelical Fellowship, "confronted me with the Gospel of Jesus Christ in my dormitory room." Soon, as Whitcomb remembers, "I surrendered to the claims and the authority of the Lord Jesus Christ." Two months later, however, the war interrupted his education. He arrived in Europe in the fall of 1944, 
serving in an artillery unit in the battle of the Bulge. Discharged in 1946, Whitcomb returned to Princeton, became a history major, and continued his spiritual studies with Fullerton, who taught Whitcomb gap creationism based on the Scofield Reference Bible, which allowed for an unaccountably long period between Genesis 1 and Genesis $2 .{ }^{4}$ When Whitcomb graduated in 1948, he was ready to serve God, and he set off for Grace Theological Seminary. After receiving his bachelor of divinity degree from Grace in 1951, Whitcomb was hired to teach the Old Testament. He was still teaching the gap theory. But he already had doubts about it after reading a new book written in defense of young-earth flood geology. That volume was titled That You Might Believe (1946); the author was twenty-eightyear-old Henry Morris. ${ }^{5}$

Born in Dallas in 1918 into a Southern Baptist family that moved around the state before finally settling in Houston, Henry Morris was baptized at the age of eight. ${ }^{6}$ Morris hoped to study journalism at the University of Texas in Austin, but as the Depression undermined his father's real estate business, Morris had to settle for Rice Institute, which he could attend for free. Morris started at Rice in 1935, barely a decade after Fort Worth-based J. Frank Norris had blasted that school for harboring evolutionists. If student newspaper reporting is any indication of prevailing views in the 1920s, Norris was not popular there. ${ }^{7}$ But Rice was congenial enough to the young Morris, who recalled that at this point he was, like John Whitcomb, "a theistic evolutionist and Sunday-morning Christian." Pursuing the more practical field of civil engineering, Morris graduated with honors in 1939.

It was only after he graduated and moved south to El Paso, where he worked for three years as an engineer for the International Boundary and Water Commission, that Morris's thinking began to change. Living away from his fiancée Mary Louise that first year, he had plenty of time to think and read the Bible. Soon Morris came to reject his theistic evolutionism and instead became convinced that God had created the earth in six twenty-four-hour days. After he and Mary Louise married, they joined a fundamentalist Baptist church in El Paso and started teaching Sunday school. Morris joined the Gideons in 1942. When he was invited to return to Rice as an instructor of civil engineering, Morris joined the InterVarsity Christian Fellowship, began advising the student Rice Christian Fellowship, and held regular Bible classes at his home. ${ }^{8}$ 
Morris, like Whitcomb, was still attracted to gap creationism, allowing as it did for both a literal six-day creation and an old earth. The best popularizer of this view was Dr. Harry Rimmer, a prolific author and spellbinding speaker. Rimmer's recently published work, The Theory of Evolution and the Facts of Science (1941), helped erode Morris's confidence in evolutionary explanations of the earth's history. ${ }^{9}$ But Rimmer's writings also introduced Morris to the work of George McCready Price and put Morris on the path to young-earth creationism.

As Morris was trying to sort out the age of the earth and the length of the days of creation, he read Price's New Geology. Morris was thrilled. Here was "scientific" confirmation of both a six-day creation and a young earth. "It was a life-changing experience for me," Morris wrote. Surely unaware of Price's frustrations in his own quest to become a noted writer, Morris, the would-be journalist, was taken with Price's knowledge of science and scripture, his "careful logic," and his "beautiful writing style." Price's work, recalled Morris, "made a profound impression on me." After reading New Geology, Morris joined the young-earth Deluge Geology Society. Over the next few years, Morris hunted down Price's other books and eventually "read most of" them as well. ${ }^{10}$

Whether those books included Price's politicized Poisoning Democracy (1920), Socialism in a Test Tube (1921), or The Predicament of Evolution (1925) is unclear. ${ }^{11}$ What is certain is that by the time Morris published his first work of Christian apologetics in 1946, That You Might Believe, he had absorbed the concept that evolution and communism were closely allied evils. Later republished as The Bible and Modern Science by the Moody Bible Institute, Morris's book was aimed at college students. They were suffering, in the author's view, from the "anti-Christian nature of the teaching" in secular institutions and even many "so-called Christian schools." Morris's inaugural work contained a chapter on evolution and another on the biblical flood. But in his very first chapter, Morris placed these topics in a contemporary political context. Given Morris's later insistence on separating his antievolutionism from politics, the attention he gives in this first work to the broader world is notable.

Morris described a chaotic world in moral decline: "The almost hopelessly confused political and international picture has its social and economic counterpart in a prodigious number of 'isms' and 'ocracies,' in the apparently irreconcilable conflict between capital and labor, in the fields of world trade and finance, in racial conflicts, in seemingly every phase of 
man's economic activity. ... Moral barriers are falling on every hand, and few people in the world any longer seem to know or care about the differences between wrong and right." 12

Even in the realm of physical science, old certainties were crumbling under the impact of Einsteinian relativity and Planck's quantum physics. So, too, was Christianity afflicted, with a profusion of "denominations, sects, and cults." 13 To confront this massive confusion, Morris offered the absolute certainty of his Christian fundamentalism.

In his chapter on the bankruptcy of evolution, Morris began by comparing the claims and logic of evolutionary science with the "fact of a creation already completed by GOD, as revealed especially in Genesis I." 14 The bulk of his attack on evolution focused mainly on the lack of factual support for that theory. He reviewed the "so-called proofs" for evolution, from Mendelian genetics to comparative anatomy to embryology to the fossil record. In later editions, Morris would add a section on creationist R.E.D. Clarke's "law of morpholysis," based on the second law of thermodynamics, which argued that nature tends to move from order to disorder. This argument against evolution from "entropy" would become a staple of creationist thought. In every single case, Morris concluded, the evidence was inadequate to support evolutionary claims. ${ }^{15}$

Before advancing this negative argument, however, Morris did provide positive "evidences" for what he called the "atheistic and satanic character" of evolutionary thought. These were the "evil social doctrines" that evolutionary thinking had "spawned." Morris pointed to the "deadly philosophies" of Nietzsche and Marx, who were both "profoundly influenced" by Darwin. The former brought the world German militarism, Nazism, and Mussolini's Fascism. From Marx, Morris wrote, "the world has inherited socialism, communism, and anarchism." There were also the "immoral doctrines" taught by Freud and Bertrand Russell. Summing up the cumulative impact of evolution, Morris considered it "unthinkable that a theory of any kind could have such far-reaching and such deadly effects as has the theory of evolution." 16

In attributing social and political evils to evolution, Morris could draw on a long tradition including Price, Riley, Norris, O’Toole, Gilbert, and others. In the list of sixteen recommended books at the end of his chapter on evolution, Morris cited recent works by Price, O’Toole's 1925 book, and perhaps most significantly, Evolution: The Root of All Isms by Dan 
Gilbert, published in a second edition only four years earlier in 1942. Gilbert stood out in the degree and explicitness with which he attributed both communism and sexual immorality to evolutionary teachings. In making the Red Dynamite argument in the 1930s and '40s, Gilbert spoke with an unusually clear voice. Morris was listening.

When Moody republished That You Might Believe in 1956, the list of recommended readings no longer included Dan Gilbert's work. Perhaps the publishers were clairvoyant. For in 1962, Gilbert, the supreme critic of the immorality of modern sex education, hit the headlines in the worst possible way. In a hotel outside San Bernardino, California, Gilbert was shot to death by Robert Marrs. Marrs's wife Martha had been having an affair with Gilbert and was pregnant with their unborn child. Robert Marrs was later acquitted of first-degree murder. ${ }^{17}$ Gilbert was not the first nor would he be the last prominent evangelical to go down in a flaming inferno of hypocrisy.

When Henry Morris published That You Might Believe in 1946, Gilbert still provided inspiration, and Morris was on track to follow in his footsteps. When he arrived later that year in Minneapolis to begin graduate study at the University of Minnesota, none other than Gilbert's mentor, the aging antievolutionist warrior William Bell Riley, summoned the young Morris to his office. Riley had read Morris's book, and he was considering Morris for the job of leading Northwestern—a job that he would soon give to Billy Graham. It could not have hurt Morris's chances that he had promoted Riley's young protégé Dan Gilbert. While Morris politely declined the job offer, Riley was correct to see in Morris's writings a continuation of what the older man had started. Not only did these two men share a fundamentalist Baptist faith, but they agreed that evolution posed great dangers for American society, morality, and politics. ${ }^{18}$

Morris may have been in step with Riley, but in the ranks of the American Scientific Affiliation (ASA), in which evangelical Christians attempted to honor both God and the latest scientific advances, Morris's young-earth perspective was losing out. Signs of this included Creation and Evolution (1950) by ASA member Russell Mixter, a professor of biology at Wheaton College. Mixter rejected a universal Noachian flood and accepted an old earth. Along with ASA colleague J. Frank Cassel, Mixter urged their ASA colleagues to adopt theistic evolutionism. "Evolution is a fact," wrote 
Cassel in $1951 .^{19}$ Then came Ramm's 1954 work that drove a wedge between Billy Graham and John R. Rice.

Now working on his graduate degrees at Grace Theological Seminary, John Whitcomb resented Ramm's book and looked for a way to strike back. Whitcomb had read That You Might Believe at Princeton. When Henry Morris appeared at Grace to speak in 1953 in defense of flood geology, Whitcomb was inspired to focus his doctoral dissertation on that subject. ${ }^{20}$ In framing his approach to geological history, Whitcomb followed the lead of Cornelius Van Til, who taught apologetics at the fundamentalist Presbyterian Westminster Theological seminary. Whereas Christian fundamentalists had generally taken an inductive, fact-based "evidentialist" approach, as reflected in the writings of both George McCready Price and Henry Morris, Van Til instead argued for "presuppositionalism." Drawing on the writings of Dutch Reformed neo-Calvinists, Van Til contended that human beings had no autonomous reasoning ability apart from the mind of God. Our starting assumptions-or "presuppositions"-predetermine our conclusions. The only starting point that can grant humans true knowledge and understanding, argued Van Til, was total acceptance of the divine revelation of scripture.

Whitcomb began the "Genesis Flood" dissertation with a bold statement of his own philosophical "starting point"- "the infallible Word of God." Since Whitcomb believed that "revealed truth" was the only way to construct an accurate history of the earth, he made "no apology" for building his "entire case" on interpretation of biblical text. If he failed to make a convincing case, Whitcomb wrote, he would lose on the "battlegrounds of the Hebrew and Greek text of Scripture" and "not on the steep and slippery heights of mountains." The word of God, not evidence from the natural world, would settle the question. ${ }^{21}$ Whitcomb proceeded to show how scriptural evidence could be aligned with the young-earth conclusions that Price had reached fifty years earlier and that Morris was reviving.

While Whitcomb claimed he did not need to employ geological facts from the natural world to make a positive biblical argument, he could not ignore the "steep and slippery heights." Like nearly all creationists before and since, he felt impelled to attack facts deployed by evolutionists. Not only did Whitcomb cite and quote Price on thrust faults, but he relied on George Barry O’Toole, "a scientist of note," whose critique of fossil 
dating methods and evidence of horse evolution Whitcomb found compelling. Whitcomb described O’Toole's 1925 book as "the most devastating attack ever made against the theory of organic evolution," and quoted long passages from it. ${ }^{22}$

In 1957, Whitcomb completed work on "The Genesis Flood" and sought to get it into print. He boldly stood on biblical authority. But he had produced a book manuscript on geological history without even a pretense of scientific method. The presuppositionalist needed an evidentialist. Whitcomb embarked on a search that eventually led him back to Morris. By then, Morris was teaching at Virginia Polytechnic Institute (VPI), where he headed up the Civil Engineering Department. What began as a plan for Morris to contribute a modest quantum of additional material ended with a book that he primarily authored. ${ }^{23}$

Among the creationist experts that Whitcomb had contacted for help was none other than George McCready Price. Then eighty-six, Price politely declined to offer his editorial services, but he did express his pleasure at seeing a new generation of creationists "coming forward to carry the torch of truth." Since Whitcomb had essentially updated Pricean flood geology, contacting Price made sense. And yet Price proved to be a public relations problem. As Morris informed Whitcomb, most scientists considered the self-taught geologist a "crackpot." Beyond Price himself, Adventism was suspect in the eyes of many evangelicals. In the end, Whitcomb and Morris carefully omitted all but a few incidental references to Price in the revised manuscript and removed all mention of his Adventism. In a letter to Price's biographer in 1964, some eighteen months after Price's death, Morris rewrote history. While "the direct influence of his writings were not significant in the preparation of our book," Morris explained, "the indirect influence was quite substantial." ${ }^{24}$ The marginalization of Price has endured in creationist collective memory. Decades later, John Morris, himself a leading creationist, claimed that his father Henry Morris "wasn't following [George] McCready Price ... [who was] a lay scientist and not a hard scientist. ... When he was writing The Genesis Flood . . . he wasn't reading theologians. ... McCready Price was a preacher, I think." 25

With the benefit of hindsight, we know that Pricean flood geology was silently present in The Genesis Flood. It also may be that his Red Dynamite thinking was there as well. Even late in his life, Price was still known 
as someone who had made this connection. In the 1950s, Price kept up a correspondence with James Bales, a professor of Bible and theology at conservative Church of Christ-affiliated Harding College in Searcy, Arkansas. Harding president George Benson had persuaded a group of fundamentalist businessmen to fund the Harding American Studies Institute, which transformed the nearly bankrupt school into a major center for anticommunist organizing. It attracted a wide range of conservative figures, including the young Ronald Reagan, who lent his voice-over talents to a series of anticommunist films. ${ }^{26}$

With a doctorate in the history and philosophy of education, Bales had become active on the evolution issue in the late 1940s, linking up with a British creationist organization called the Evolution Protest Movement (EPM). Initial publicity for EPM, in 1932, had sought to awaken the British public to the dangers of evolution in ways that resonated with Price's early writings: "Christianity sanctifies the individual and the home; Evolution glorifies the herd and is the parent of Socialism and Communism; In Russia the theory of Evolution has supplanted Christianity. Darwin is the new Messiah." ${ }^{27}$ Bales was increasingly outspoken about communism, publishing Atheism's Faith and Fruits in 1951 and later working with Billy James Hargis's anticommunist Christian Crusade. ${ }^{28}$ In 1954, Bales contacted Price about his anticommunist activism, and Price suggested he read Poisoning Democracy. Bales thanked him for the suggestion and stated that Price was "exactly right" about the connection between evolution and communism. In a 1959 letter, Bales again complimented Price for his foresight. ${ }^{29}$ Decades after Price had invented the "Red Dynamite" label, his views seemed more relevant than ever.

Even though Henry Morris shared Price's anticommunist perspective, Morris's job in The Genesis Flood was to showcase science, not politics. Compared to Morris's discussion of communism in That You Might Believe, the politics is easy to miss in The Genesis Flood. It comes at the very end of the book, after some four hundred pages devoted to detailed analyses of the size and capacity of the ark, Lyell's uniformitarianism, volcanism, the antediluvian vapor blanket, radiocarbon dating methods, and dinosaurs. Not only did Whitcomb lean heavily on O'Toole's critique of evolutionary science, but Morris tipped his hat to O'Toole's organizational strategy, as the author saves for the afterword 
his castigation of evolution for its baleful social, moral, and political consequences. And yet last is not least.

In the book's seventh and final chapter, which bears the distinctly apolitical-sounding title "Problems in Biblical Geology," readers encounter a summary section titled "Modern Significance of the Genesis Flood." It is here that Whitcomb and Morris explain the "Importance of the Question." Was the earth created, or did it evolve? Was the flood local or universal? These are "not mere academic questions," the authors insist. To the contrary, argue Whitcomb and Morris, "one's conviction about them may have deep influence upon his whole philosophy of life, and therefore, perhaps even upon his ultimate destiny." ${ }^{30}$ Moreover, it is not just that evolutionary thinking and behavior may consign individuals to eternal damnation. Beyond this, as Whitcomb and Morris proceed to demonstrate, evolution creates a moral, social, and political hell on earth.

In order to join together evolution and communism, they begin by affirming that there are only two basic philosophies: God-centered and man-centered. In the second, human beings are capable of providing for themselves. Underlying that philosophy, the authors charge, is "the concept of evolution!" Any notion that humans can improve their earthly conditions-by their own efforts-is powered by evolutionary thinking and is an insult to God. This blasphemous idea, Whitcomb and Morris argue, is found in all non-Christian religions and philosophies, "be these ancient idolatries or primitive animism or modern existentialism or atheistic communism!" 31

Noting that theistic evolutionism was more popular in America than the atheistic variety, Whitcomb and Morris observed that the same was not true in the Communist world. Atheistic evolutionism formed "the backbone of the whole scientific structure of Communistic philosophy." The authors then quoted Engels's funeral oration for Marx about his collaborator's affinity with Darwin and repeated the still-accepted story that Marx offered to dedicate Das Kapital to Darwin. Linking communism to other "man-centered" philosophies, Whitcomb and Morris assigned it a special place: "Communism is the most dangerous and widespread philosophy opposing Christianity today."

Even if communism was not sweeping the United States in the early 1960s, humanistic social sciences were thoroughly "permeated" by evolutionary thought. Since these fields of study had a "more immediate impact 
on actual human relationships and conduct" than did biological science, they posed a greater threat to society "than most people realize." Morris and Whitcomb followed the example of Riley, Norris, Gilbert, and others who had shone a spotlight on social science. They concluded the discussion of the "Importance of the Question" by making the ultimate source of that danger unmistakable: the "pride and deception of the great adversary, Satan himself." 32

The Genesis Flood made Morris both famous and infamous. At VPI, the book quickly isolated Morris among his colleagues. The liberal pastor of the local Blacksburg Baptist Church relieved Morris of his Sunday school duties. "He was pretty much run out of town by the open-minded liberal faculty there at Virginia Tech," recalled son John Morris. But before leaving VPI, Henry Morris joined with other fundamentalist-minded colleagues to found the College Baptist Church (now the Harvest Baptist Church), affiliated with the Independent Fundamental Churches of America. ${ }^{33}$

Morris was suddenly in demand as a creationist speaker. While the bulk of the attention garnered by the book focused on the scientificsounding support the authors provided for a six-day creation, their political message continued to be heard. On September 10, 1962, Morris spoke to some five hundred members of the Houston Geological Society. The bulk of his talk concerned the false "presuppositions" of uniformitarian geology. But the way Morris ended the talk was strikingly un-geological. Morris stated that "there is much more at stake here than simply a matter of geologic interpretation." Evolutionary science, he argued, had invaded "nearly every aspect of human life" and was the basis of Dewey's progressive education, Nietzschean ethics, Fascism, and Nazism. Significantly, he added, "even more seriously . . . modern Communism today is grounded squarely on the theory of evolution." He then cited Jesus's warning about "evil fruit" and urged his listeners to seriously investigate "the nature of the tree itself." 34 The chairman of the group ended the meeting abruptly without leaving any time for discussion, later apologizing to Morris after some of the Houston geologists lodged a complaint. Still, some of the attendees spoke with Morris afterward, and a few of them expressed "full agreement." ${ }^{35}$

With the Cold War in full swing, most Americans took the threat of communism seriously in early September 1962, only weeks before the 
Cuban Missile Crisis. That morning's front-page headlines reported on anti-Castro Cubans in the US appealing to the Kennedy administration to help overthrow the Castro regime; the possibility of war with Cuba; and the downing of US-made U2 aircraft sent by Taiwan into Communist Chinese airspace. ${ }^{36}$ In January 1963, Morris sent Price a copy of the talk, writing that he thought Price "might be particularly interested in the enclosed paper" and letting him know that the Houston crowd was "surprisingly friendly." This was the last letter Morris wrote to Price, who died about two weeks later, at the age of ninety-two. ${ }^{37}$

Morris continued to connect evolution and communism. In The Twilight of Evolution (1963), reprinted twenty-six times through 1990, Morris further developed his political "fruit" argument. The book was based on a series of sermons that the newly famous Morris delivered to the annual meeting of the Reformed Fellowship in Grand Rapids, Michigan. Twilight had one big advantage over Whitcomb and Morris's blockbuster: it was only ninety-seven pages long. Unlike The Genesis Flood, which began with the arcane details of the biblical account and the accompanying creationist science, Twilight began with the "fruits" of evolution. In the book's first chapter, "The Influence of Evolution," Morris made a revealing and strikingly pragmatic argument. After establishing that evolution reigned supreme in the nation's halls of science, Morris clarified why Christians should care. If evolution were "merely a scientific theory affecting the interpretation of the data of biology, geology, and astronomy," Morris explained, "we would not be too concerned." If evolutionary science could be reconciled with the Bible (although Morris insisted this could not be done), Christians "would be quite content to leave the subject to these scientists to work out on their own."

But evolution had massive consequences. The pro-evolutionary social science disciplines of sociology and psychology had a profound effect on "social orders." Political philosophies and movements animated by evolution had similar effects. As examples, Morris offered up communism, socialism, militarism, "and even the anti-Christian aspects of modern capitalism and colonialism." The attempt to distinguish and salvage a godly, moral, Christian capitalism from the exceptional instances of exploitation, attributed to anti-Christian evolutionary ideas, would continue to feature in Morris's work. But here, Morris devoted more detail to socialists than to unnamed evolutionist robber barons. Again citing Marx's admiration for Darwin, Morris pointed to socialist evolutionists of the 
Second International and "modern Soviet writers," all of whom grounded their doctrines of "class struggle" and "atheistic materialism" in Darwinism. Hitler and Mussolini-identified with "racism and militarism"-also appeared in Morris's evolutionary pantheon. In Morris's eyes, evolution also undergirded Freudianism, behaviorism, and "Kinseyism." Morris summed up the "tremendous" and "deleterious" impact of evolution by citing the Gospel of Matthew and its "bitter fruit." 38

Finally, evolution was evil. Morris expanded his argument, presented briefly in The Genesis Flood, that Darwinism was based on Satan's rebellion against God. Here Morris posed the question of how evolutionary thinking could persist if it contradicted both science and the Bible. His reply: "The answer is Satan!" The deceiver had "fathered this monstrous lie of evolution, for he is the father of lies." Citing John, Ephesians, Luke, and Corinthians, Morris provided textual evidence for the deceptive character of the devil. Just as George McCready Price had warned about a coming despotism, Morris warned that the communist-inspired United Nations-and "its multitudinous tentacles"-foreshadowed a Sataninspired, human-centered world government that would culminate in the Antichrist. Meanwhile, the "evil progeny" of evolution—which included socialism and communism-was spreading "in terrifying profusion" around the world. ${ }^{39}$ Morris could not have made it clearer why Biblebelieving Christians needed to stop the evolutionists in their tracks.

Even before the publication of The Genesis Flood, Morris had been thinking about setting up a new creationist organization. In 1963, the Creation Research Society (CRS) was born. Walter Lammerts (1904-1996), a Missouri Synod Lutheran and PhD in genetics who taught horticulture at UCLA, served as the group's first president and editor of the Creation Research Society Quarterly (CRSQ). Lammerts represented a new breed of young-earth creationists who did not lack for academic bona fides. ${ }^{40}$ Members of the CRS board of directors held numerous advanced degrees in science. These included Bolton Davidheiser, a Johns Hopkins-trained zoologist, and Duane Gish, who had earned a PhD in biochemistry from the University of California at Berkeley. ${ }^{41}$ "Voting members" of the CRS, who elected the board, were required to have an advanced scientific degree. Without that credential, one could still be a "sustaining member." By 1967 , the CRS had roughly two hundred voting members and six 


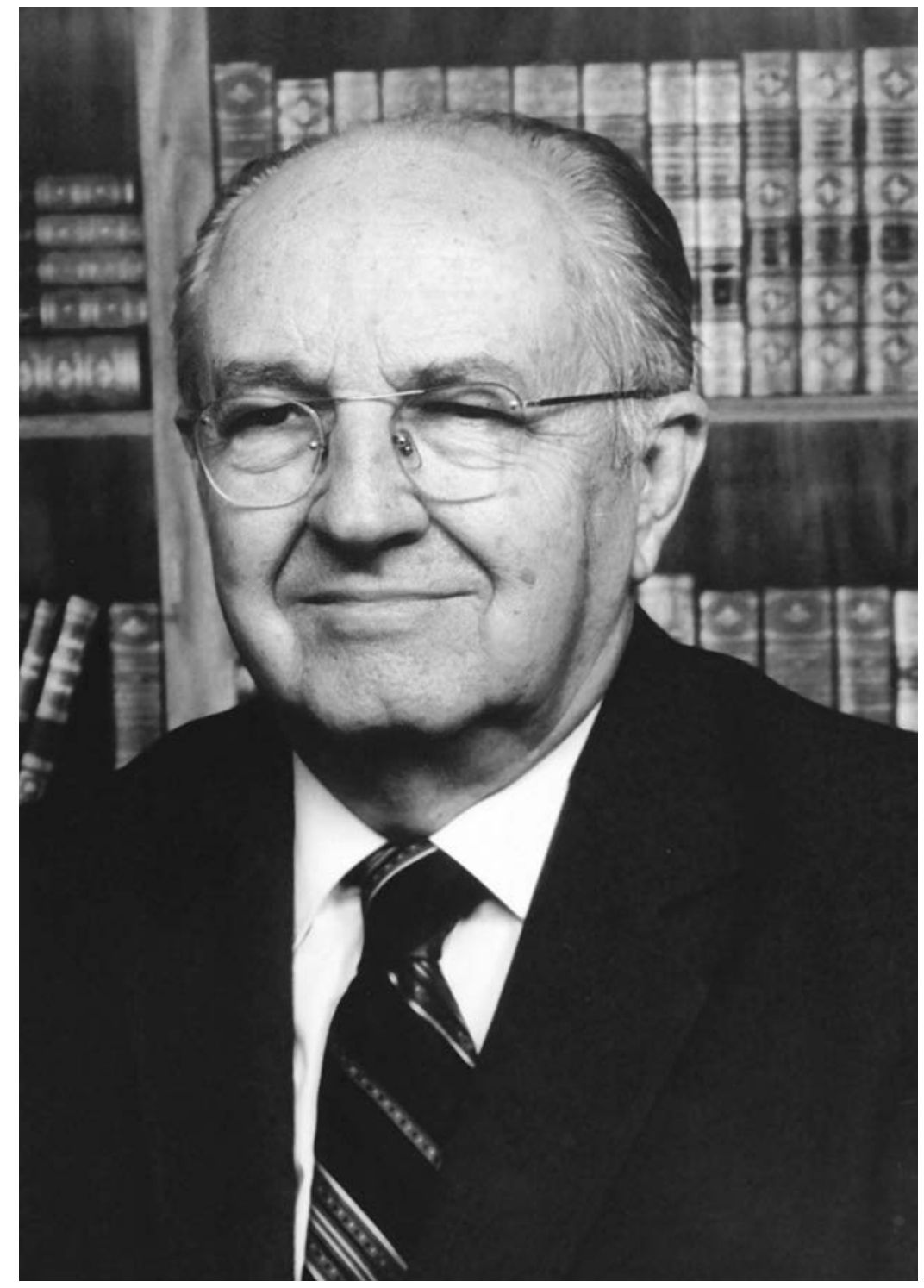

Figure 11. Henry M. Morris, founder of the Creation Research Society and the Institute for Creation Research. The coauthor of The Genesis Flood (1961), which claimed that science supported young-earth creationism, Morris argued that evolution mattered because its "evil fruits" were so harmful to humanity. Institute for Creation Research. Used by permission. 
hundred sustainers. ${ }^{42}$ The organizational base for the ICR (and the future breakaway group, Answers in Genesis) was under way.

Articles in the early CRSQ centered on evolutionary topics such as fossil bacteria, the origins of the tetrapod limb, and microflora of the Grand Canyon. The prevalence of "real" science might suggest that Henry Morris's own interest in the social and political consequences of evolutionary thought was neglected. It was not, however, owing to the exertions of several key contributors. Prominent among them was John N. Moore, who served for nearly twenty years as the managing editor of CRSQ. As Morris relates, Moore had earned an MA in biology and an $\mathrm{EdD}$ in science education and taught natural science at Michigan State University (MSU). ${ }^{43}$ What Morris does not mention is Moore's anticommunist politics.

During the early 1960s, when CRS was getting off the ground, Moore was anything but quiet about his extra-scientific views. Cosponsor of the student Conservative Club at MSU, he opposed allowing Communist speakers on campus, and his actions made local headlines in early 1961. Moore stepped up the pressure later that year when he sent a letter to the Van Buren County Farm Bureau, charging that MSU was dominated by communist ideology and was muzzling conservatives. The Farm Bureau reprinted his list of charges in its next newsletter, and the MSU faculty senate agreed to investigate Moore's claims. Moore was a regular speaker at meetings of the Daughters of the American Revolution, holding forth on the value of the American flag and the dangers of "ultra-liberalism" on campus. Joining with members of the Michigan Republican Conservatives in 1963, where the crowd listened to a taped address by presidential hopeful Senator Barry Goldwater, Moore chaired a forum about education. And at Hillsdale College in 1964, Moore spoke about the "consequences of scientific methodology" when used in the social sciences, arts, and humanities. ${ }^{44}$

Most likely that methodology was “evolutionary," since Moore's contributions to the CRSQ harped precisely on the noxious effects of evolutionary thinking on academia. In "Neo-Darwinism and Society," Moore began with a quotation from Richard Weaver's Ideas Have Consequences, which called attention to a false sense that society has been progressing. To the contrary, as Moore summarized Weaver, ever since the rise of empiricism, in which experience rather than transcendent values and ideals rule, society has been on the downgrade. Unfounded faith in human 
reason and a "philosophy of materialism" thus led to Darwinism in biology, Marxism in economics, and both behaviorism and psychoanalysis, the latter two based on "naturalistic 'drives' or 'urges' of sexual behavior."

While Moore tended to write in a humorless, formal manner, he emphasized the affinity of Darwinism and Marxism in earthier terms: "Darwinism was clutched to the bosom of Karl Marx and Frederick Engels." This broad change in thinking-moving away from the authority of Godhad caused what Moore called an "indoctrination of the intelligentsia." Having established the general downward trend, Moore examined three academic fields reflecting it—history, economics, and literature. Each one, Moore concluded, was built on a false, evolutionary, materialist foundation. The negative impact on public policy, Moore told CRSQ readers, has been "colossal." 45

Considering that he addressed a subject that often excited passionate debate, perhaps Moore's relentless "scientific" logic and formalism offered a refreshing change of tone for his readers. He could not be accused of being unclear, as he included diagrams demonstrating the causal links between Darwinian ideas and their social and political consequences. ${ }^{46}$ He could be persuasive, as we know from the published account of one young evangelical by the name of Zola Levitt. Born into an Orthodox Jewish family, Levitt became a born-again Christian in 1971. By the mid-1970s, Levitt was a well-known premillennial dispensationalist who specialized in the subject of Israel's role in the end-time. ${ }^{47}$ While he was still sorting through the implications of his newfound faith, Levitt met Moore, who helped convince him that he must reject evolution. ${ }^{48}$ Levitt's resulting book, Creation: A Scientist's Choice, is an extended answer to a question that Levitt posed to Moore-what does it matter whether or not one believes in evolution? Moore's response did not focus primarily on the evidence for the findings of evolutionary biologists. Rather, it reproduced his claim that ideas have consequences. As Moore told Levitt, "World conditions are a good example of what occurs when people live by evolutionary thinking." Communist ideology, Moore told Levitt, originated with evolutionary thinking. Stalin's work camps were a form of the principle of the "survival of the fittest." As Levitt summarized this view, "Somehow Darwin's The Origin of Species led to Solzhenitsyn's The Gulag Archipelago." More broadly, the way we behave toward other human beings is a product of how we think of their essential nature. "If we believe we 
descended from animals," Levitt learned from Moore, "then we will tend to behave like animals, in accordance with such lineage." 49

As one might expect, Levitt's book received high marks from a CRSQ reviewer. CRS supporter G. Richard Culp fully endorsed Moore's argument that evolution held responsibility for "crumbling moral standards" and that evolution-inspired "agnosticism" had led to the "monstrous systems of fascism and bolshevism." Culp hoped that Levitt's book would be widely read and would help young people find Jesus. Some readers might have been surprised to see a second review in the same issue, this one by CRS president Walter Lammerts. He joined Culp in endorsing the book's basic antievolution message. He parted company, however, with Moore's attribution of communism to evolution. Communism arose, in Lammerts's view, as a natural reaction to czarist oppression. "Capitalism" at the turn of the century had been very "harsh." But fortunately, Lammerts explained, conditions improved owing to the efforts of progressive politicians such as Robert LaFollette and "progressive capitalists" such as Henry Ford.

Lammerts did not fit the stereotype of creationist conservatism: a civil rights-supporting "Kennedy Democrat" in the fold of young-earth creation science who had little patience for the John Birch Society. ${ }^{50}$ And yet he fit the description of an anticommunist Cold War liberal. Lammerts attributed improvements in workplace safety and higher wages not to the organized efforts of the labor movement but rather to an anticommunist and Jew-baiting auto magnate. Lammerts remained on relatively good terms with Henry Morris, who had made Moore's “ideas have consequences" argument in his own writings since 1946. It may have been a matter of style-Morris subtly wove his anticommunism into a broader tapestry of "creation science," while Moore was making headlines and wildly waving his political flag.

Somewhere in between the two was Bolton Davidheiser, the evolutionary zoologist turned antievolutionist who briefly served on the CRS board in the late 1960s. ${ }^{51}$ In 1969, Davidheiser's Evolution and Christian Faith was published by the Presbyterian and Reformed Publishing Company, which had also brought out The Genesis Flood. In a favorable appraisal of the book in CRSQ, a reviewer placed Davidheiser's work alongside Morris and Whitcomb's creationist landmark: "What the Genesis Flood did with respect to geology, Dr. Bolton Davidheiser has done with respect 
to biology." The book ranged widely, providing a long history of evolutionary thought going back to the ancient Greek materialist Empedocles, whose role as the "father of the evolution idea" was recognized by many evolutionists. Just as Morris and Whitcomb had supposedly demonstrated the validity of a young earth, Davidheiser had reviewed the scientific evidence for biological evolution and convincingly showed it to come up short. ${ }^{52}$ For all his interest in comparing Davidheiser's book to The Genesis Flood, the CRSQ reviewer chose not to comment on one intriguing similarity-its politics came at the end. After devoting some 350 pages to biology, Davidheiser turned to the subject of "Social Darwinism." Here, the author linked Darwin's ideas with American robber barons, with European imperialists and militarists, with Nietzsche, Mussolini, and Hitler.

Davidheiser's reviewer-Rousas J. Rushdoony (1916-2001)—was not unaware of the relationship between evolutionary biology and politics. Rushdoony later became infamous as the founder of Christian Reconstructionism. Unlike the premillennialists who populated Baptist and Methodist (and Seventh-day Adventist) congregations and foresaw a terrible apocalypse preceding the second coming of Christ, Rushdoony, like many Presbyterians and others in the Reformed tradition, was a postmillennialist. Jesus would return for his thousand-year reign only after human beings had reconstructed a modern-day version of what Adam and Eve had lost. Christians would first establish God's kingdom and reassert "dominion" over the earth, following God's command in the book of Genesis. Published in 1973, Rushdoony's Calvin-inspired Institutes of Biblical Law provided a blueprint for his distinctive vision. He called for the reestablishment of biblical law (including stoning as punishment) as the basis for a decentralized Christian theocracy (in his words, "a theonomy," for God's law) in America. Since Rushdoony's Reconstructionism (or Dominionism) occupied a place outside mainstream Christian evangelicalism, his early role in the rise of young-earth creationism has received little notice..$^{53}$ But it was significant and helps illuminate the Red Dynamite story.

Scion of an Ottoman Armenian immigrant family, Rushdoony was born in New York shortly after his parents narrowly escaped the genocide carried out by the Ottoman Turks against the Armenian people during World War I. He arrived in 1934 as a freshman at the University of 
California with leftist sympathies. But as he was exposed to the variety of materialist and evolutionary "isms" that had alarmed the young Dan Gilbert-who had recently left the University of Nevada-Rushdoony began to challenge his professors. ${ }^{54}$ Unlike Gilbert, Rushdoony seemed to relish academic disputation, as he remained at Berkeley for his MA in English literature. He attended a local, theologically modernist seminary, after which he was ordained as a minister in the mainline Presbyterian Church U.S.A. Moving rightward, Rushdoony worked closely with medieval historian Ernst Kantorowicz, a German-Jewish refugee who arrived in the US in 1940 and was fired from Berkeley in 1950 for refusing to take a McCarthyist loyalty oath. Unlike other such refugee scholars, however, Kantorowicz was nowhere near being a communist. He was a theologically minded historian and a staunch German nationalist. After fighting in the German army in World War I, he had volunteered for the ultra-right Munich Freikorps, which battled communists in the streets and included in its ranks a young Adolf Hitler. ${ }^{55}$

Rushdoony's intellectual turning point came after he left Berkeley, while he was serving as a missionary to Paiute and Shoshone people in northern Nevada. Along with his family's experience of persecution by Ottoman authorities, and his alienation from theological modernism, the plight of Native Americans helped deepen a Christian-infused hostility to the modern secular state. At the same time, Rushdoony had also absorbed a relatively optimistic Calvinist postmillennialism, which dictated that saved Christians must construct God's kingdom on earth before the second coming of Jesus. This eschatology also bespoke an appealing confidence that such a reconstructed America could be built. As he worked to create a little Christian commonwealth among the Native American people of northern Nevada, he continued to harbor academic ambitions. Rushdoony authored a book manuscript on Christian ritual and British politics and submitted it to the University of Chicago Press. They turned him down, and Rushdoony began to give up hope of making his mark either on the academy or on the reservation.

Thanks to a minister friend, he came upon a copy of the writings of Cornelius Van Til. ${ }^{56}$ The uncompromising nature of Van Til's position was hardly new to Christian fundamentalism, but the way it was recast as a theory of knowledge appealed to those, like Rushdoony, who were seeking more secure intellectual foundation for their theological ideas. Starting 
in 1952, when Rushdoony and his family left Nevada for Santa Cruz, California, where he began pastoring a Presbyterian church, he gradually became more outspoken. In 1958, he left the Presbyterian Church U.S.A. and joined Van Til's Orthodox Presbyterian Church. That year, he published his first book, in which he offered the following Tilian formulation: "All facts being created facts, factuality can only be understood in subordination to God. But to understand factuality, man needs a norm and this Scripture provides." 57

In 1962, Rushdoony left pastoring for good, and he began full-time work for a series of libertarian conservative think tanks, including the Center of American Studies. ${ }^{58}$ After internal battles left Rushdoony on the sidelines, he moved in 1965 to start Chalcedon Inc. in Vallecito, California (later the Chalcedon Foundation), named for the AD 451 Ecumenical Council of Chalcedon. At this historic meeting, the church fathers clarified the nature of the human and divine character of Jesus Christ: the two were in perfect union-coexisting but unmixed. Since the human and divine were separate, this fact clarified that no man-even a king-could ever be divine. But despite this clear guidance, human beings had disregarded Chalcedon. They had set themselves up as gods, through their elevation of autonomous human reason and the power of the secular state. ${ }^{59}$ For more than three decades, at the helm of the Chalcedon Foundation, Rushdoony sought to undo humanity's perverse handiwork.

Considering that the rejection of his first book manuscript changed the course of R.J. Rushdoony's life, it is appropriate that his contribution to the rise of the modern young-earth creationist movement also concerned a book seeking a publisher. In 1960, Rushdoony was called upon by the Moody Institute Press to review The Genesis Flood manuscript. Despite Rushdoony's positive review, Moody decided not to publish. Undeterred, Rushdoony suggested that the authors approach Presbyterian and Reformed Publishing, a small press owned by his friend Charles $\mathrm{H}$. Craig, who had published Rushdoony's first book two years earlier. Craig admired George McCready Price and was thrilled to publish a book that seemed to confirm Price's "flood geology." 60

After providing this crucial bit of young-earth creationist midwifery, Rushdoony continued to collaborate with Henry Morris and the CRS. In 1965, the year Rushdoony founded Chalcedon, he contributed a critique of evolutionary thought to the pages of the CRSQ. Rushdoony used 
the case study of "evolutionary scientist" Sigmund Freud to demonstrate, in Van Tilian fashion, that only a Christian faith could produce true science. Gilbert and other antievolutionists had held up Freud as an example of how evolutionary thinking justified sexual animalism. Rushdoony was more philosophical. Freud had used discredited Lamarckian arguments about the inheritance of acquired characteristics to explain features of human psychology-an explanation Rushdoony described as relying on the "miraculous." Freud did so, Rushdoony suggested, because there was no credible evolutionary alternative, only a mysterious and equally fantastical notion of some life-force built into the universe. ${ }^{61}$ For Rushdoony, this meant that anyone attempting to argue from a non-Christian perspective inevitably and unconsciously "reintroduces His attributes" in a distorted form. We cannot think, that is, without God. If we want to reach the truth, we need to accept the true source of all knowledge-creation by the "totally self-conscious ontological Trinity." 62

If Rushdoony's presuppositional philosophy might have been a bit obscure for CRSQ readers, he soon showed that he could pitch creationism to a broader audience. In 1966, Rushdoony wrote a pamphlet and helped produce an accompanying educational filmstrip (reviewed in CRSQ), both titled The Necessity of Creationism. The seven-page pamphlet was published and distributed to thousands of readers the next year by the Bible Science Association, which worked closely with the CRS and specialized in carrying "creationism to the masses." 63 As many antievolutionists had done before him, Rushdoony began by posing the question of why his readers should care about evolutionary science. Short of accepting Darwin wholesale, one could easily join with Bernard Ramm and "harmonize" science and the Bible. What, as he put it, is "at stake" ? Rushdoony offered three reasons why readers should reject both Darwin and Ramm. First, if one allowed for any one part of the Bible to be questioned, the entire fabric fell apart. Second-and again invoking Tilian arguments-the antiGod "presuppositions” undermine a true, Christian science.

Third, and most expansively, Rushdoony explained to readers how evolution could "affect the mind and welfare of man." According to evolutionary thinking, man was no longer created in the image of God. Rather than the active subject called up by God to exercise "dominion" over the earth, he was the passive product of earthly evolution. Humanity then replaced God with the tyrannical, "total state," as in ancient Egypt, 
whose rulers followed a proto-evolutionary philosophy. Evolution produced "slavery," and modern "totalitarian" thinkers, such as Karl Marx, welcomed Darwin's ideas as "the necessary foundation for socialism." "If men put their faith in evolution," Rushdoony wrote, bolding his text for emphasis, "they will then look to scientific socialist planners for salvation rather than to Jesus Christ."

In such conditions, man became "the primary experimental animal." Since he is no longer held to account by an eternal godly moral code, his morals were reshaped by the social environment. Thus, evolution ushered in a "Pavlovian world," in which humans would be conditioned to behave in an immoral and "lawless" fashion. Without Christian morality and law, evolutionarily inspired Americans would run amok. To illustrate the consequent moral decline, Rushdoony quoted, in horror, from a handout produced at UCLA by Bruins for Voluntary Parenthood and Sexual Liberty, a group supporting abortion rights, birth control, and freedom from repressive sexual codes: "Where there is no victim, every act is morally right." He also pointed to the "moral breakdown" in America's big cities, where people lock their homes up tight to protect themselves from nihilistic, anarchistic, evolutionary-thinking "monstrous new barbarians." Like John R. Rice, J. Frank Norris, and others, Rushdoony saw only one solution: a renewal of "Biblical Christianity." Unlike the Baptist premillennialists, including Henry Morris, Rushdoony did not invoke the signs of the end times. He was girding for the grim struggle to retake America that lay ahead.

In a review of the filmstrip version of the pamphlet, CRSQ editor George Howe acknowledged the challenge Rushdoony faced in bringing "the dry bones" of philosophical discourse to life, but judged that the effort had succeeded. The audiotape accompanying the filmstrip closely followed the text of the published pamphlet, including Rushdoony's claim about "socialist planners" versus "Jesus Christ." The review indicates some of the graphic aids employed in conveying Rushdoony's ideas. They included an "evolution tree" (presented twice during the filmstrip) whose evil "fruit" was nourished by "anti-god and anti-biblical roots." Howe helpfully summarized the rest: thirty-three photos, including six portraits; fourteen Bible passages; eleven color diagrams; eighteen pictures of the Bible or other books or magazines; eight still lifes; four great works of art; and five historical pictures, including scenes from ancient 
Egypt and a portrayal of Noah's ark. Howe concluded that high school students would "find this filmstrip of great value." ${ }^{64}$ In view of the dazzling array of high-technology educational tools available to teachers in the early twentieth-first century, it is easy to underestimate the impact of the lowly filmstrip and cassette tape. But they were at the cutting edge of "audiovisual" teaching technology in the mid-1960s. Rushdoony, who went on to become a major proponent of Christian homeschooling, may well have helped Henry Morris and his counterparts to see the potential in making creationism accessible. ${ }^{65}$

As Morris and Whitcomb began to gather a cadre of scientific creationists and like-minded thinkers in the mid-1960s, they gained allies from the broader world of Christian fundamentalism. Among the earliest was David Noebel (1937-), who would play a major role in illuminating the connections between evolution and communism and keeping those fires burning well into the twenty-first century. Born in Oshkosh, Wisconsin, in 1937, Noebel grew up in the nondenominational Lakeview Church, where he served as president of his youth group and committed his life to Jesus at the age of fifteen. After high school, he headed off to Milwaukee Bible College and then transferred to Hope College in Holland, Michigan, where he graduated cum laude with a degree in philosophy in 1959. Noebel was ordained as a minister in 1961, but the twenty-four-year-old was not done studying philosophy. He began pursuing his doctorate at the University of Wisconsin, under Arthur C. Garnett (1894-1970), a prominent philosopher of religion. ${ }^{66}$

By his own account, the liberal Madison campus tested Noebel's faith. ${ }^{67}$ But Noebel passed the test and by the early 1960s had become a devout Christian conservative and a staunch anticommunist. In 1961, Noebel began pastoring the Fundamental Bible Church in Madison. At a neighboring church that year, Noebel spoke on "The Threat of Communism," showing the congregation the recently completed film CommunistLed Riots against the House Committee on Un-American Activities in San Francisco, May 12-14, 1960, better known by its short title, Operation Abolition. Produced by the US House Committee on Un-American Activities (HUAC), the film contained footage of recent student demonstrations in San Francisco organized against local HUAC hearings. According to the film's narrators, the students were dupes of "professional Communist 
agitators," including leaders of the International Longshoremen's Association subpoenaed to testify. ${ }^{68}$

Having gained some press, Noebel took a further step into politics in 1962 when he challenged Representative Robert Kastenmeier, the incumbent liberal Democrat, for the Second Congressional District seat. Running as an independent Republican, Noebel made his main issue "international communism." He vowed not to settle for "stalemate" but to fight for "victory." ${ }^{69}$ Noebel lost the Republican primary election but garnered more than one-third of the party faithful vote and won suburban Waukesha County, the largest Republican stronghold in the state. ${ }^{70}$ Noebel's electoral experience would serve him well as he developed into a skilled anticommunist activist.

As Noebel honed his political skills, a primary influence on the young activist's thinking was an Australian-born surgeon, marriage counselor, and psychiatrist who had an unlikely name for a Christian anticommunist powerhouse: Fred C. Schwarz. Dr. Schwarz helped Noebel and a whole generation of anticommunists think about the links between Marxist philosophy and evolutionary science. The son of a Viennese-born Jew who converted to fundamentalist Baptism, Schwarz first came to the US under the auspices of Presbyterian Carl McIntire and Baptist T. T. Shields, of the militantly separatist fundamentalist ACCC and its international branch, the ICCC. In 1953, with the encouragement of Billy Graham and others, Schwarz founded the Christian Anti-Communism Crusade (CACC). ${ }^{71}$ Linking Christianity and anticommunism was hardly novel, but Schwarz had a talent for clear and provocative analysis.

Understanding how the communists thought, as Schwarz saw it, would enable anticommunists to predict their next moves and ultimately defeat them. A conservative who challenged communism without understanding the philosophy of dialectical materialism, Schwarz insisted, was akin to a dairy farmer who aimed to maximize milk production but had no interest whatsoever in cows. ${ }^{72}$ Schwarz quickly developed a reputation as an authoritative speaker. His first two books-The Heart, Mind, and Soul of Communism (1952) and Communism: Diagnosis and Treatment (1956)educated anticommunist Americans about the roots of communist thought in accessible fashion but also with serious attention to Marxist classics like Engels's Origin of the Family, Private Property, and the State. ${ }^{73}$ 
Schwarz's big break in came in 1957 when HUAC invited him to testify on "the communist mind." Consistent with Schwarz's attention to philosophical matters, he made the evolutionary foundations of communism clear. According to Schwarz, the communists were guided by "scientific laws" that rested on materialist foundations: atheism, the "material animal nature of man," and economic determinism. To underline the evolutionary point, Schwarz quoted the US Communist Party chief William Z. Foster: "Henceforth, the evolution of human species must be done artificially by the conscious action of man himself."

Schwarz indicted Communist evolutionism in two ways. First, Communists denied that humans were created in God's image, that we had a spiritual nature. Second, Communists' evolutionary view of humanity rendered us as little more than "expendable animals" to be used and killed for higher Communist purposes. As Schwarz told the committee, it was not just that Communists killed. The "tragedy" was that they committed murder and then transformed it into "a moral and righteous act." Communism was, thus, "ruthless and amoral." Summing up what he called "the great evil" of communism, Schwarz pointed to the "philosophic, basic concepts" of a movement that "materializes and bestializes man."74 Thus did Schwarz invent a verb-form for the "beast" vocabulary that had been evolving over the previous century. But his political logic was old school, echoing the charge that John R. Rice had made in his 1954 "Dangerous Triplets" sermon-that communists were committed to whatever tactic would enable them to "win," whether it was murder, lying, stealing, or rape.

If twenty-year-old David Noebel had not yet heard of Schwarz in the spring of 1957 , he most likely had heard of him by the end of that year. Thanks to the efforts of the Milwaukee-based Allen-Bradley Company, Schwarz's testimony was widely reprinted. For two decades, Allen-Bradley's owners had contended with workers organized into Local 1111 of the United Electrical Workers, a labor union with significant Communist Party influence. The company supported the John Birch Society and the American Enterprise Association (precursor of the American Enterprise Institute), a "non-partisan" research group that promoted the value of the free-market system and the dangers of labor unionism. ${ }^{75}$ Allen-Bradley's owners viewed Schwarz's teaching on the nature of the communist "disease" as worth their investment. 
In the fall of 1957 , the company spent roughly $\$ 150,000$ placing the entire text of Schwarz's testimony-as a full-page ad-in nearly thirty major newspapers and distributing hundreds of thousands of copies around the country. Released on December 22, the ad bore an alarmist headline: "WILL YOU BE FREE TO CELEBRATE CHRISTMAS IN THE FUTURE?" Subheadlines answered the question for readers. Among these: "NOT UNLESS You and other free Americans begin to understand and appreciate the benefits provided by God under the American free enterprise system." The ad rhetorically asked readers if "preservation of your life" was worth taking forty-five minutes to read Schwarz's words. If readers were dubious, Allen-Bradley's advertising managers helpfully selected sections of text and instructed readers to "pay attention to the material in bold type." Among the bolded sections was Schwarz's charge that communism "materializes and bestializes man." Schwarz reported to ACCC members that Allen-Bradley spurred others to follow suit. They included the American Legion and a host of companies, including the Southwestern Savings and Loan Association of Houston, which ordered ten thousand copies of Schwarz's testimony to send to all its account holders. ${ }^{76}$

This was only the beginning of Schwarz's rapid-fire ascent to anticommunist fame. In the early 1960s, he organized a series of anticommunist schools around the US. In Southern California, he mobilized an impressive coalition of politicians, businessmen, Hollywood actors, and celebrity entertainers to put on a series of giant spectacles. One high point was "AntiCommunism Week" in Los Angeles, endorsed by forty-one area mayors. It featured "Youth night" at the Los Angeles Sports Arena, attended by a crowd of sixteen thousand young people. Speakers included Roy Rogers, John Wayne, and Ronald Reagan, whose speech brought the crowd to their feet. Closing the show, and echoing antievolutionist Gerald Winrod's "funny" comment decades earlier about his own children, singer Pat Boone declared, "I don't want to live in a Communist United States. I would rather see my four girls shot and die as little girls who have faith in God than leave them to die some years later as godless, faithless, soulless Communists." 77 Fred Schwarz and his followers helped thousands of conservative Christians understand in their bones why anticommunism mattered.

Along with Dr. Schwarz, the other major influence on David Noebel's career was Billy James Hargis. He would catapult Noebel into national 
prominence and cement his reputation, for good or ill, as an expert on the fruits of evolution. Like J. Frank Norris, Hargis grew up in the American Southwest into a working-class family. Born in Texarkana, Texas, in 1925, and adopted by Jimmie and Laura Hargis, young Billy found Christ at the age of nine. The family attended the Rose Hill Christian Church, affiliated with the Disciples of Christ. At the age of ten, while his mother was undergoing life-threatening surgery, Hargis prayed to God and promised that if his mother lived through her ordeal, he would devote the remainder of his life to Jesus. In his own inimitable way, Hargis kept his promise. $^{78}$

In 1943, after graduating from Texarkana High School and finishing one year of classes at the Ozark Bible College in Bentonville, Arkansas, the future home of the Walmart empire, Hargis was ordained a Disciples of Christ minister. In his early sermons, Hargis gained practice in the tradition of Oklahoma "bawl and jump" preaching but was not yet a conservative firebrand. Under the influence of the Disciples reform tradition, Hargis touted the virtues of pacifism and world government. But settling for several years in Sapulpa, Oklahoma, near Tulsa, Hargis became acquainted with A. B. McReynolds, an influential Disciples of Christ soul-winner and conservative activist. Feeding Hargis a steady stream of anticommunist writings, including John Flynn's The Road Ahead, McReynolds convinced Hargis that "the Federal Council [of Churches] was perverting the Gospel, undermining the Church, getting her involved in left-wing political activities, and I wanted no part of it." The young preacher decided to take a stand.

In 1948, Hargis began publishing Christian Echoes, which informed readers of the dangers posed by "deadly satanic-inspired Communism." Hargis attracted national attention, as he increasingly took to the radio waves. J. Frank Norris took note of Hargis in the pages of the Fundamentalist: "He is the Pastor of a great church. ... He is a Pre-Millennialist and belongs to that great crowd of believers and evangelists of all denominations. He is a man of courage and deepest consecration." Two years later, Hargis left his Sapulpa pastorate, renamed the paper Christian Crusade, and launched the eponymous Tulsa-based organization that was the center of his work for the next two decades. ${ }^{79}$

The "Crusades" against communism operated by Hargis and Schwarz occupied some common ground. Both leaders had an internationalist 
vision and collaborated with separatist fundamentalist Carl McIntire. In 1953, Hargis received publicity when, with McIntire's ICCC, he launched from West Germany six thousand balloons attached to Bible verses into Eastern Europe. With the triumph of the 1959 Cuban Revolution, Hargis paid increasing attention to Fidel Castro and Soviet designs on Latin America. He enlisted as a Christian Crusade lecturer Fernando Penabaz, a prominent Cuban attorney and editor who had turned against the revolutionary government, came to the US in 1960, and joined Hargis on a nationwide anticommunist speaking tour called Operation: America Awake. ${ }^{80}$

Hargis also helped publicize the case of Rev. Richard Wurmbrand, a Jewish-born Romanian and former Communist who converted to Christianity. An ordained Anglican and Lutheran minister, Wurmbrand was imprisoned twice for sedition by the Stalinist Romanian regime, until he finally won amnesty and moved to the US. Testifying in 1966 before a US Senate subcommittee investigating Communist persecution of religion, Wurmbrand stripped to his waist to reveal the scars he said were the marks of his torture by his Romanian Communist captors. Wurmbrand's account of the ordeal-Tortured for Christ (1967)—won him a wide hearing among American conservatives. The Christian Crusade distributed Wurmbrand's book, sponsored joint speaking tours, and featured the pastor's story in the Christian Crusade, with a front-page cover photo of the anticommunist Christian martyr shaking hands with Billy James Hargis. ${ }^{81}$ Among the American evangelicals who were captivated by Wurmbrand's story was Henry Morris, who would later cite Wurmbrand on the satanic character of Marxism.

Despite their common interest in global anticommunism, Billy James Hargis and Fred Schwarz were very different people. Schwarz offered a well-researched, carefully articulated summary of Marxist philosophy. Hargis was a persuasive speaker. But he had little patience for study that seemed irrelevant to his immediate needs. Looking back at his short stay at Ozark Bible College, Hargis admitted that while the dean was a "genius" in teaching the Greek language, he himself had no interest in taking his course "since I didn't intend to preach to any Greeks." 82 What Hargis may have lacked in personal inclination, however, he more than compensated for in recruiting a team of prominent and dedicated conservative educators, led by the young Rev. David Noebel, to staff a summer training 
school in the Rocky Mountains that would arm the nation's youth to do battle with socialism and Satan.

In June 1962, Hargis announced that the Christian Crusade had bought the Grand View Hotel in Manitou Springs, Colorado, nestled in the foothills of Pikes Peak, and renamed it the Summit Hotel. The following summer, David Noebel held the first session of the Crusade's Anti-Communist Youth University (ACYU). Also called the Summit School (and later rechristened Summit Ministries), the ACYU began classes in the summer of 1963. Thirty-six young people, age fourteen and up, attended the first summer session. Noebel, affectionately known by the students as "Doc," served as dean and one of the instructors. In the early days, he also did building maintenance, while his wife Alice did the cooking. Cost per student, which included room, board, tuition, and books, was $\$ 100$ (approximately $\$ 865$ today). That first summer, some 70 percent of the students were on full scholarship. Scholarship funds were contributed by Christian Crusade subscribers and other donors. ${ }^{83}$

A foundational Bible passage for the ACYU, which later provided the title for one of Noebel's best known books, came from 1 Chronicles 12, in which King David is gathering tens of thousands of "mighty men" to wage war. One of the smallest bands stands out in importance: "And of the children of Issachar, which were men that had understanding of the times, to know what Israel ought to do." Wisdom was a powerful weapon. As one of Noebel's supporters later commented, "Doc" aimed to equip young Christians with the knowledge so that they could resist the "attractive, but false worldviews penetrating and destroying Western Civilization." 84 Noebel emulated Fred Schwarz by insisting that a thorough examination of the enemy's philosophy was essential to doing Christian combat.

The multifaceted communist enemy was addressed in a wide range of talks to Summit students that first summer in 1963. Hargis, who would be a regular feature at Summit, spoke on "The National Council of Churches," "International Communism," and "Christ vs. Anti-Christ (God out of Schools)." Journalist and intelligence agent Edward Hunter, who accused the Chinese Communists of "brainwashing," spoke on this topic and delivered a two-part lecture on "Dialectical Materialism." 85 Noebel spoke on "The United Nations," “The Book of Revelation," "Internal Communism," and "The Seed of Woman (A Tale of Two Cities)." 
Another member of the faculty was General Edwin Walker (1909-1993), who had become an ultraconservative cause célèbre when he resigned his commission after clashing with the Joint Chiefs for his promotion of John Birch Society views to his troops. In 1962, Walker was arrested (and then briefly institutionalized under orders from US Attorney General Robert F. Kennedy) after he helped to organize armed attacks on civil rights activists supporting the admission of James Meredith at the University of Mississippi. Walker-described by Noebel as a "heroic patriot-soldier"—spoke at Summit on "The Extremist," "A Definition of a Communist," and "Building Americanism." 86

Finally, "Evolution" was the subject of teaching conducted by W.O.H. Garman (1899-1983). Born in Philadelphia, Garman embraced the fundamentalism of the Philadelphia School of the Bible. This training girded him for the more modernistic teachings at the Pittsburgh Theological Seminary, from which he emerged in 1925 as an ordained United Presbyterian minister. In an early sermon, Garman focused his fire on communists, labor unionists, members of "other devil created organizations" as the "onrushing forces of the Anti Christ." ${ }^{87}$ In addition to his pastoring duties, Garman led several national fundamentalist organizations. The first, from 1942 to 1981, was the Associated Gospel Churches, a group formed for the explicit purpose of getting fundamentalist chaplains into the US armed forces. The second was the Independent Fundamental Churches of America, which Henry Morris and his supporters had joined in Blacksburg after publication of The Genesis Flood. The third was McIntire's ACCC, over which Garman presided from 1947 to 1950. Garman was fully on board with the central message of Noebel's venture, offering a lecture on "Communism and Our Churches." Based on Garman's writings, it is reasonable to conclude that he, like Morris himself, viewed evolution and communism as related evils. In a pamphlet published by the ACCC, Garman denounced the Federal Council of Churches and "their modernistic and communistic activities. $" 88$

Summit students would have been hard pressed to avoid the Red Dynamite message. The curriculum prominently included books like Communism: Its Faith and Fallacies (1962) by Harding College's James Bales. Bales explained that communists denied the existence of God and maintained instead that "matter created life and that life's manifold forms, including man, have evolved without the operation of any force or forces 
beyond those which we see working in matter today." Bales challenged the idea that, in dialectical fashion, matter (and then life) might have emerged from non-matter. ${ }^{89}$ Students also read The Naked Communist (1958) by Mormon fundamentalist W. Cleon Skousen, who accurately informed students that "Dialectical Materialism is an evolutionary philosophy." 90 Finally, Dean David Noebel was adept at tracing the connections between the Marxism and evolutionism, as he would later detail in Understanding the Times (1996). Its chapters on Marxism, secular humanism, and biology, Noebel has claimed, reflect the accumulated experience of his Summit teaching. ${ }^{91}$ America's anticommunist youth were well equipped in the Colorado mountains to do ideological battle.

By the middle of the 1960s, Henry Morris and his colleagues at the Creation Research Society had made gains, but they were missing a key ingredient: an organizer who could provide a strong administrative platform for Morris's young-earth creationist views and make them accessible to the Christian masses. Enter Tim LaHaye (1926-2016). The man who would decades later become the millionaire coauthor of the Left Behind novel series and a mover and shaker in the high politics of the Christian Right had a modest start in life. Born in 1926 in Detroit, LaHaye was the son of Frank and Margaret (Palmer) LaHaye. He was raised as a fundamentalist Baptist, his mother serving as a fellowship director at a local Baptist church. ${ }^{92}$ His father, the son of French Canadian immigrants, worked at a Detroit Ford plant as a mechanic. When Tim was only a toddler, the family moved out to the small town of Farmington. ${ }^{93}$

Tim LaHaye might have grown to adulthood in Farmington but for the tragic event that took place on April 13, 1936, just two weeks shy of his tenth birthday: his father, age thirty-four, died of a heart attack. As Tim LaHaye later related, his despondency was mitigated only by the comment of his pastor, who said, "This is not the end of Frank LaHaye; because he accepted Jesus, the day will come when the Lord will shout from heaven and descend, and the dead in Christ will rise first and then we'll be caught up together to meet him in the air." "All of a sudden," LaHaye recalled, "there was hope in my heart I'd see my father again." ${ }^{4}$ That hope powered his dispensationalist conviction that no matter how badly things might seem, in the end, the righteous will be reunited in heaven. 
We have only a glimpse of how Tim LaHaye's upbringing may have shaped his political views. With a father who worked at Ford while the battle over the UAW was raging, Tim might well have heard J. Frank Norris's sermons over the family radio. We do know, however, that already as a young man, LaHaye was critical of Roosevelt's New Deal. After Frank LaHaye's death, the family moved back to Detroit, where twelve-year-old Tim sold newspapers on the streets to help his mother make ends meet. She worked at a hospital and later in a war-industry plant, all the while studying at the Detroit Bible Institute. When the child-labor provisions of the federal 1938 Fair Labor Standards Act cost Tim this job, LaHaye recalls, "I remember coming home and telling my mother what I thought of politicians who mess around with our lives." If LaHaye was unhappy with Dr. New Deal, he was perhaps fonder of Dr. Win-the-War. At the age of eighteen, after finishing night school and briefly attending a Chicago Bible institute, he joined the Army Air Forces and served the last year of the war in uniform. ${ }^{95}$

The religio-political war that LaHaye would wage for decades to come began the next year when he enrolled in 1946 at fundamentalist Bob Jones University. If Tim LaHaye had any lingering thoughts about the validity of evolutionary ideas, they would have been crushed at Bob Jones, where instructors enforced a militant antievolutionism. On that Greenville, South Carolina, campus LaHaye developed a different kind of crush, on fellow student Beverly Jean Ratcliffe, a like-minded Detroit native who embraced a fundamentalist Baptist dispensationalism, and the two married in 1947. She would go on to lead the Christian conservative charge alongside her husband, as author, speaker, and organizer. After graduating in 1950, the LaHayes moved with their growing family from South Carolina to Minnesota, and then in 1956 to the San Diego area. That year, Tim LaHaye became pastor of Scott Memorial Baptist Church, in the San Diego suburb of El Cajon, and the LaHayes began to make connections in this hotbed of Christian conservatism. In the first of many joint activist ventures, Tim and Beverly began cohosting a half-hour weekly radio and then television program titled The LaHayes on Family Life. ${ }^{96}$

By the early 1960s, LaHaye had firmly committed himself to anticommunist activism. He appeared in an early John Birch Society film explaining why he joined. It was not until he read Birch material that he realized 
that the "liberal takeover" of church and country were "parallel." LaHaye hesitated to join the Birch Society since he preferred not to "mix religion and politics." But then he realized that if the communists were not stopped, Christians would not be free to preach the gospel. Having volunteered for service against the national enemy in World War II, LaHaye felt he could do no less, now that Americans confronted "the greatest enemy our country has ever faced." 97

Among the evils perpetuated by the communists, in the minds California conservatives, was "the smut problem." According to El Cajon-based California assemblyman and Methodist minister E. Richard Barnes, a veteran "anti-obscenity" crusader who had headed up the San Diego chapter of Fred Schwarz's Christian Anti-Communism Crusade, the communists had mounted a "Satanic assault on the whole structure of American life." Around 1964, LaHaye teamed up with Barnes to launch California League Enlisting Action Now (CLEAN) to oppose pornography and sex education. In 1966, CLEAN campaigned for Proposition 16, which cracked down on the pornography industry and enlisted the support of the Republican candidate for governor Ronald Reagan. ${ }^{98}$

LaHaye had become sufficiently convinced of the urgency of the communist threat to American youth that he saw the need for Christian parents to band together and create their own educational institutions. Since the mid-1950s, when Carey Daniel offered his church in Dallas to house a private, fundamentalist, antievolutionary segregated school system, the movement for private Christian schools had grown. It was boosted by US Supreme Court rulings in Engel v. Vitale (1962), making school prayer unconstitutional, and Abbington v. Schempp (1963), doing the same for Bible reading in school. In 1965, LaHaye founded Christian High School as an adjunct to Scott Memorial Baptist. Only sixteen seniors graduated in 1967. But as LaHaye and others convinced conservative Christians that keeping their children in public schools was a mistake, enrollment boomed. By 1979, there were some five thousand such schools in the US, with more than one million students. ${ }^{99}$ In San Diego County, by 1981, there were nine schools and some twenty-five hundred students in what became the Christian Unified School District, still under the aegis of Scott Memorial and the LaHayes. ${ }^{100}$ Scott Memorial grew as well during these years. It tripled in size between 1956 and 
1971, and later, under pastor David Jeremiah, it became one of the first "mega-churches" in the US.

In the 1960s, Scott Memorial's growth was due in large part to the increasing popularity of the work that Tim and Beverly LaHaye did to popularize a Christian approach to psychology and marriage counseling. Building on a decade of their broadcasts on family life, Tim LaHaye published the Spirit-Controlled Temperament in 1966, the first of a long series of Christian self-help books issuing from the LaHayes over subsequent decades. In his inaugural effort, LaHaye offered a fundamentalist Christian spin upon the ancient Greek temperament theory. All human beings, that is, were born with one of the four basic temperamentssanguine, choleric, melancholic, and phlegmatic. By identifying their distinctive temperaments, readers could gain greater insight into themselves and achieve greater satisfaction in their relationship with others. LaHaye drew on the work of Norwegian theologian Ole Hallesby, whose work on temperament theory was published in English just four years earlier as Temperament and the Christian Faith (1962). Following Hallesby, LaHaye claimed that when someone was reborn in Jesus Christ, that person could acquire a new temperament or combination of old and new. ${ }^{101}$

In a supreme irony, LaHaye, who would come to be identified with modern creationism, had based his first book on ancient protoevolutionary thinkers. Temperament theory rested on the claim by Empedocles that there were four elements: fire, air, earth, and water. As the creationist Bolton Davidheiser had noted, Empedocles could be considered the original evolutionist. LaHaye did encounter some resistance from fellow Christian counselors. ${ }^{102}$ But this did not seem to matter to his readers. Given the cultural tumult of the 1960s, they were eager for practical tools to help them navigate the storm. Spirit-Controlled Temperament made the Religious Best Sellers List, based on a national sample of bookstores affiliated with the Christian Booksellers Association. ${ }^{103}$ LaHaye was in high demand as an authority on Christian psychology. Addressing Christians about the intimate realm of their personal relationships, LaHaye always kept the big apocalyptic picture in mind. In 1971, when, on the invitation of the city's ministerial association, LaHaye gave a weeklong series of talks in the community building of Greeley, Colorado, his 
nightly topics came in pairs, such as "Keys to Wedded Bliss" and "When God Destroys Russia." 104 No dimension of human experience was too small or too large for Tim LaHaye to illuminate for his conservative Christian flock.

As LaHaye continued to raise his public profile, he crossed paths with Henry Morris. In early 1970, they both spoke at a conference named for the esteemed early fundamentalist Reuben Torrey, editor of the original Fundamentals, at Biola College (formerly the Bible Institute of Los Angeles), which Torrey had helped lead in its heady early days. Both men had been thinking about establishing an institution of higher learning that could teach creation science. For LaHaye, a San Diego-based college would complete the chain that he had begun with Christian high school five years earlier. He was familiar with Morris's writings and asked him to teach creationism at his planned college. In his written response to LaHaye, Morris expressed great enthusiasm for taking the fight against evolution to a higher level. "I do believe that the issue of Biblical creationism is the most urgent issue confronting Christianity today," Morris wrote. "The evolutionary system is at the root of most of the spiritual and moral problems that have arisen to hinder the gospel and its proclamation today." Whether or not LaHaye had read Morris's work that linked communism and evolution, he surely agreed that communism was an evil fruit of the satanic turn the country had taken.

Morris not only underlined the importance of creationism, but he also emphasized the kind of educational institution that was needed. It would not be enough to create another Christian "college." Rather, Morris envisioned a "Christian university," which could offer a graduate program in scientific creationism. Such a "nerve-center" of "Biblical truth," wrote Morris, would "prepare and send out solid Christians in various strategic professional fields as well as posts of full-time Christian service." ${ }^{105}$ In the fall of 1970, Christian Heritage College opened its doors on the grounds of Scott Memorial Baptist Church. LaHaye was president, and Morris served as academic vice president. Morris wrote a statement of faith that reflected a premillennial, pre-tribulation, Baptist fundamentalism, but also specified tenets of Morris's young-earth creationism: creation of all things in "six natural days" and a worldwide flood. The initial entering class at $\mathrm{CHC}$ was only a "handful." The 
initial degree programs were meager in number: Bible, Education, Mission, and Liberal Arts. ${ }^{106}$ But the convergence of LaHaye's and Morris's Christian ambitions would soon facilitate the transformation of Morris's CRS into the Institute for Creation Research and change the face of creationism for decades to come. 